\title{
Physico-chemical properties and associated active microbes of tea garden waste of Golaghat district of Assam, India
}

*Apurba Saikia, Pavitra Chutia' and Satya Ranjan Sarmah²

\author{
*Department of Life Sciences, \\ Dibrugarh University, DIBRUGARH, ASSAM \\ ${ }^{1}$ P. G. Department of Life Sciences, \\ D. R. College, GOLAGHAT, ASSAM \\ ${ }^{2}$ Mycology \& Microbiology Department, \\ Tocklai Tea Research Institute, \\ JORHAT, ASSAM. \\ *Corresponding Author \\ E-mail : apurba30saikia@rediffmail.com
}

Received : 20.09.2020; Revised : 09.10.2020; Accepted : 25.10.2020

\begin{tabular}{l} 
ABSTRACT \\
Tea Gardens generally produce two kinds of waste materials such as Tea Factory waste (TFW) and Pruning Litter (PL). \\
Minimum $2 \%$ of TFW is produced as by - product during processing of tea contributing a huge quantity as waste material. \\
Similarly during pruning operations considerable amount of biomass are produced. Both the bio-waste materials can be \\
managed by biological process to produce value added organic supplement to enrich the soil of tea plantation. During the \\
present study different physico-chemical properties, viz. $\mathrm{pH}, \mathrm{P}_{2} \mathrm{O}_{2}, \mathrm{~K}_{2} \mathrm{O}$ and nitrogen's of TFW were analyzed. In TFW the value \\
of Total soluble solids ranged $(27.2-31.1 \%)$ and Crude fiber ranged $(25.83-31.12 \%)$ and Caffenine amount ranged (23.14- \\
$27.94 \%)$ and Total ash ranged (3.15-6.54\%) The aflavin ranged $(0.45-0.76 \%)$ and the arubignins ranged (18.45-21.32\%). In \\
TFW and PL some beneficial and active microbial populations are found which can be used in tea plants after making value \\
added compost to increase their natural productivity. In this study focus was given to explore the beneficial and active \\
microorganisms found in TFW and PL and found some beneficial microbes such as Actinomycetes, Azotobacter, Azospirillum \\
and Phosphate solubilizing bacteria respectively. \\
\hline Figure : $01 \quad$ References : 17 \\
KEY WORDS: Assam, Ecology, Microbe, Pruning, Tea waste.
\end{tabular}

\section{Introduction}

Tea is a popular drink made from the Camellia sinensis $(L)$ Kuntze. Tea of Assam is famous all over the world due to its quality and properties. It is the most economically important crop of the country. This plant is widely distributed in acidic soils of tropic and sub-tropical region of the world. In 2018, Assam had produced 691.91 million $\mathrm{kg}$ tea and in 2019, Assam produced a whopping 715.79 million $\mathrm{kg}$ of tea, which are $51.55 \%$ of the all India tea production that year (Tea Board of India). In the processing of tea generally the two leaves and a bud are plucked from the tea plants and are processed for producing various grades of teas. In tea gardens two kinds of waste materials are produced : Factory tea waste (FTW) and Pruning litter (PL). In the processing of tea leaves, a measurable quantity of wastes are produced in the tea processing factories which are either left as waste material or of less economical value. Apart from this, in the tea gardens during pruning operation huge quantity of pruning litter are produced which may be converted to value added organic fertilizer.

In India, yearly production of tea is $27.4 \%$ of total world production ${ }^{14}$. During the tea processing period the fibre portion of the tea is discharged from tea factory. The tea waste is a by-product from tea dust after decaffeination process which is a solid waste that can be used in various ways. Apart from losing the economic value of the waste, a huge amount of capital is expended in disposing it. Moreover the wastes constitute environmental hazards through indiscriminate dumping

ACKNOWLEDGEMENTS: The authors express their gratitude and thanks to the Head of the Department of Life Sciences, Dibrugarh University and Principal Debraj Roy College, Golaghat and Director, Tocklai Tea Research Institute, Jorhat, Assam for providing necessary facilities during the course of present study. 
TABLE-1: Amount of Nitrogen, phosphorus and potassium in the Tea Factory Waste (TFW) of different gardens of Golaghat District of Assam

\begin{tabular}{l|l|c|c|c}
\hline $\begin{array}{l}\text { S. } \\
\text { No }\end{array}$ & $\begin{array}{l}\text { Name of } \\
\text { the Tea } \\
\text { Estate }\end{array}$ & $\mathbf{N}(\%)$ & $\begin{array}{l}\mathbf{P}_{2} \mathbf{O}_{2} \\
(\%)\end{array}$ & $\begin{array}{l}\mathbf{K}_{2} \mathbf{O} \\
(\%)\end{array}$ \\
\hline 1 & Athabari & 2.45 & 0.50 & 1.47 \\
\hline 2 & Behora & 2.51 & 0.51 & 1.49 \\
\hline 3 & Borjan & 2.49 & 0.52 & 1.47 \\
\hline 4 & Doria & 2.51 & 0.46 & 1.39 \\
\hline 5 & Halmora & 2.48 & 0.45 & 1.30 \\
\hline 6 & Hatikhuli & 2.56 & 0.47 & 1.67 \\
\hline 7 & Hautoli & 2.49 & 0.56 & 1.49 \\
\hline 8 & Negheriting & 2.40 & 0.49 & 1.45 \\
\hline 9 & Pavojan & 2.60 & 0.58 & 1.48 \\
\hline
\end{tabular}

$\mathrm{N}=$ Total Nitrogen, $\mathrm{P}_{2} \mathrm{O}_{2}=$ Phosphate, $\mathrm{K}_{2} \mathrm{O}=$ Potassium and incineration. Tea waste can be a great source of biodegradable garbage and it can make a good source of compost as well. The compost prepared by using tea waste increases concentration of essential nutrients needed for plant growth and development as compared to inorganic fertilizers ${ }^{6}$.

Pruning is very important practice, next to the plucking of tea leaves in gardens which basically directly determines the quality and productivity of tea plants. Tea plants are pruned every year to obtain a given form and height and to obtain healthier and better quality of tea plants. Pruning must be done periodically and if pruning is not done or is delayed, the size and weight of growing shoots reduces on plucking ${ }^{12}$. Pruning increases the lateral branches and number of tender leaves of tea plants so it is a essential agronomic practice ${ }^{8,9}$.

To increase the productivity and less infection of pests and diseases, all tea plants are pruned every year all over the world, pruning increases the branching, improves tea quality and suppress the diseases ${ }^{7,17}$. The pruned branches of tea plants, leafs contain considerable amount of nutrients which after the decomposition returns to the soil and increases the fertility of soil, improves the physico-chemical properties of soil ${ }^{16}$. After the decomposition of pruning litter would produce allelopathic compounds such as phenol, alkaloids and flavanoids,

TABLE-2 : Amount of Total soluble solids, Crude fibre, Caffenine, Total ash, Theaflavins and Thearubigins in the Tea Factory Waste (TFW) of different gardens of Golaghat District of Assam

\begin{tabular}{l|c|c|c|c|c|c}
\hline Name of tea estate & TSS(\%) & $\mathbf{C F}(\%)$ & $\mathbf{C a}(\%)$ & $\mathrm{TA}(\%)$ & $\mathrm{Th}(\%)$ & $\mathrm{Tb}(\%)$ \\
\hline Athabari & 27.9 & 26.98 & 25.46 & 6.45 & 0.64 & 18.46 \\
\hline Behora & 28.9 & 29.25 & 27.78 & 3.15 & 0.45 & 19.34 \\
\hline Borjan & 29.8 & 26.93 & 23.14 & 6.54 & 0.65 & 19.42 \\
\hline Doria & 29.4 & 25.83 & 24.34 & 5.35 & 0.46 & 19.34 \\
\hline Halmora & 31.1 & 28.12 & 23.23 & 5.57 & 0.76 & 21.32 \\
\hline Hatikhuli & 29.2 & 28.56 & 23.34 & 4.23 & 0.45 & 18.45 \\
\hline Hautoli & 30.1 & 29.83 & 27.94 & 3.21 & 0.56 & 20.21 \\
\hline Negheriting & 27.2 & 28.01 & 26.93 & 6.53 & 0.65 & 19.42 \\
\hline Pavojan & 28.8 & 31.12 & 27.23 & 3.22 & 0.56 & 21.23 \\
\hline
\end{tabular}

TSS=Total Soluble Solids, $\mathrm{CF}=$ Crude fibre, $\mathrm{Ca}=$ Caffenine, $\mathrm{TA}=$ Total ash, $\mathrm{Th}=$ Theaflavins, $\mathrm{Tb}=$ Thearubigins 
Physico-chemical properties and associated active microbes of tea garden waste of Golaghat district of Assam, India 249

TABLE-3: Estimation of beneficial microbial population from TFW of different Tea Estates, of Golaghat district

\begin{tabular}{|c|c|c|c|c|c|}
\hline \multicolumn{2}{|l|}{ Athabari Tea Estate } & \multicolumn{2}{|l|}{ Behora Tea Estate } & \multicolumn{2}{|l|}{ Borjan Tea Estate } \\
\hline \multicolumn{2}{|c|}{$\begin{array}{l}\text { Observation in } 72 \text { hours (cfu/g) } \\
\text { sample is } 10^{5} \text { Dilution }\end{array}$} & \multicolumn{2}{|c|}{$\begin{array}{l}\text { Observation in } 72 \text { hours (cfu/g) } \\
\text { sample is } 10^{5} \text { Dilution }\end{array}$} & \multicolumn{2}{|c|}{$\begin{array}{l}\text { Observation in } 72 \text { hours (cfu/g) } \\
\text { sample is } 10^{5} \text { Dilution }\end{array}$} \\
\hline Active microbes & Mean & Active microbes & Mean & Active microbes & Mean \\
\hline Phosphate solublizer & 6.6 & Phosphate solublizer & 4.3 & Phosphate solublizer & 8.3 \\
\hline Azotobacter & 2.6 & Azotobacter & 3.3 & Azotobacter & 3.3 \\
\hline Azosprilliunm & 8.0 & Azosprilliunm & 5.3 & Azosprilliunm & 10.0 \\
\hline Actinomycetes & 2.6 & Actinomycetes & 1.0 & Actinomycetes & 3.3 \\
\hline
\end{tabular}

\begin{tabular}{|c|c|c|c|c|c|}
\hline \multicolumn{2}{|l|}{ Doria Tea Estate } & \multicolumn{2}{|l|}{ Halmora Tea Estate } & \multicolumn{2}{|l|}{ Hatikhuli Tea Estate } \\
\hline $\begin{array}{l}\text { Observation in } 72 \text { ho } \\
\text { sample is } 10^{5} \text { Dilutior }\end{array}$ & $s(c f u / g)$ & $\begin{array}{l}\text { Observation in } 72 \text { hours } \\
\text { sample is } 10^{5} \text { Dilution }\end{array}$ & fu/g) & $\begin{array}{l}\text { Observation in } 72 \text { hours } \\
\text { sample is } 10^{5} \text { Dilution }\end{array}$ & (cfu/g) \\
\hline Active microbes & Mean & Active microbes & Mean & Active microbes & Mean \\
\hline Phosphate solublizer & 5.6 & Phosphate solublizer & 3.5 & Phosphate solublizer & 7.1 \\
\hline Azotobacter & 2.6 & Azotobacter & 6.1 & Azotobacter & 3.1 \\
\hline Azosprilliunm & 7.1 & Azosprilliunm & 4.0 & Azosprilliunm & 9.0 \\
\hline Actinomycetes & 3.0 & Actinomycetes & 2.0 & Actinomycetes & 2.8 \\
\hline
\end{tabular}

\begin{tabular}{l|l|l|l|l|l}
\multicolumn{2}{l|}{ Hautoli Tea Estate } & \multicolumn{2}{c|}{ Negheriting Tea Estate } & \multicolumn{2}{c}{ Pavojan Tea Estate } \\
\hline $\begin{array}{l}\text { Observation in 72 hours (cfu/g) } \\
\text { sample is } \mathbf{1 0} \text { Dilution }\end{array}$ & $\begin{array}{l}\text { Observation in 72 hours (cfu/g) } \\
\text { sample is } \mathbf{1 0} \text { Dilution }\end{array}$ & \multicolumn{2}{l}{$\begin{array}{l}\text { Observation in 72 hours (cfu/g) } \\
\text { sample is } 10^{5} \text { Dilution }\end{array}$} \\
\hline Active microbes & Mean & Active microbes & Mean & Active microbes & Mean \\
\hline Phosphate solublizer & 6.1 & Phosphate solublizer & 2.5 & Phosphate solublizer & 7.1 \\
\hline Azotobacter & 3.1 & Azotobacter & 7.1 & Azotobacter & 2.0 \\
\hline Azosprilliunm & 2.6 & Azosprilliunm & 4.0 & Azosprilliunm & 10.0 \\
\hline Actinomycetes & 6.8 & Actinomycetes & 3.1 & Actinomycetes & 2.5 \\
\hline
\end{tabular}


TABLE-4 : Estimation of beneficial microbial population from PL of different Tea Estates of Golaghat district

\begin{tabular}{l|l|l|l|l|l}
\hline \multicolumn{2}{l|}{ Athabari Tea Estate } & \multicolumn{2}{|c|}{ Behora Tea Estate } & \multicolumn{2}{c}{ Borjan Tea Estate } \\
\hline $\begin{array}{l}\text { Observation in } \mathbf{7 2} \text { hours (cfu/g) } \\
\text { sample is } \mathbf{1 0} \text { Dilution }\end{array}$ & \multicolumn{2}{l|l}{$\begin{array}{l}\text { Observation in } \mathbf{7 2} \text { hours (cfu/g) } \\
\text { sample is } \mathbf{1 0} \text { Dilution }\end{array}$} & \multicolumn{2}{l}{$\begin{array}{l}\text { Observation in 72 hours (cfu/g) } \\
\text { sample is } \mathbf{1 0} \text { Dilution }\end{array}$} \\
\hline Active microbes & Mean & Active microbes & Mean & Active microbes & Mean \\
\hline Phosphate solublizer & 8.6 & Phosphate solublizer & 7.3 & Phosphate solublizer & 7.0 \\
\hline Azotobacter & 10.6 & Azotobacter & 7.3 & Azotobacter & 12.0 \\
\hline Azosprilliunm & 6.3 & Azosprilliunm & 8.6 & Azosprilliunm & 11.0 \\
\hline Actinomycetes & 3.6 & Actinomycetes & 5.0 & Actinomycetes & 3.6 \\
\hline
\end{tabular}

\begin{tabular}{|c|c|c|c|c|c|}
\hline \multicolumn{2}{|l|}{ Doria Tea Estate } & \multicolumn{2}{|l|}{ Halmora Tea Estate } & \multicolumn{2}{|l|}{ Hatikhuli Tea Estate } \\
\hline \multicolumn{2}{|c|}{$\begin{array}{l}\text { Observation in } 72 \text { hours (cfu/g) } \\
\text { sample is } 10^{5} \text { Dilution }\end{array}$} & \multicolumn{2}{|c|}{$\begin{array}{l}\text { Observation in } 72 \text { hours (cfu/g) } \\
\text { sample is } 10^{5} \text { Dilution }\end{array}$} & \multicolumn{2}{|c|}{$\begin{array}{l}\text { Observation in } 72 \text { hours (cfu/g) } \\
\text { sample is } 10^{5} \text { Dilution }\end{array}$} \\
\hline Active microbes & Mean & Active microbes & Mean & Active microbes & Mean \\
\hline Phosphate solublizer & 9.1 & Phosphate solublizer & 8.1 & Phosphate solublizer & 6.1 \\
\hline Azotobacter & 10.1 & Azotobacter & 7.1 & Azotobacter & 11.1 \\
\hline Azosprilliunm & 5.6 & Azosprilliunm & 8.4 & Azosprilliunm & 12.0 \\
\hline Actinomycetes & 2.1 & Actinomycetes & 4.1 & Actinomycetes & 3.4 \\
\hline
\end{tabular}

\begin{tabular}{l|l|l|l|l|l}
\multicolumn{2}{l|}{ Hautoli Tea Estate } & \multicolumn{2}{c|}{ Negheriting Tea Estate } & \multicolumn{2}{c}{ Pavojan Tea Estate } \\
\hline $\begin{array}{l}\text { Observation in 72 hours (cfu/g) } \\
\text { sample is } \mathbf{1 0} \text { Dilution }\end{array}$ & \multicolumn{2}{l|}{$\begin{array}{l}\text { Observation in 72 hours (cfu/g) } \\
\text { sample is } \mathbf{1 0} \text { Dilution }\end{array}$} & \multicolumn{2}{l}{$\begin{array}{l}\text { Observation in 72 hours (cfu/g) } \\
\text { sample is } 10^{5} \text { Dilution }\end{array}$} \\
\hline Active microbes & Mean & Active microbes & Mean & Active microbes & Mean \\
\hline Phosphate solublizer & 10.1 & Phosphate solublizer & 11.1 & Phosphate solublizer & 9.1 \\
\hline Azotobacter & 10.3 & Azotobacter & 6.2 & Azotobacter & 8.1 \\
\hline Azosprilliunm & 4.2 & Azosprilliunm & 9.1 & Azosprilliunm & 7.2 \\
\hline Actinomycetes & 3.1 & Actinomycetes & 3.1 & Actinomycetes & 2.1 \\
\hline
\end{tabular}


Physico-chemical properties and associated active microbes of tea garden waste of Golaghat district of Assam, India 251

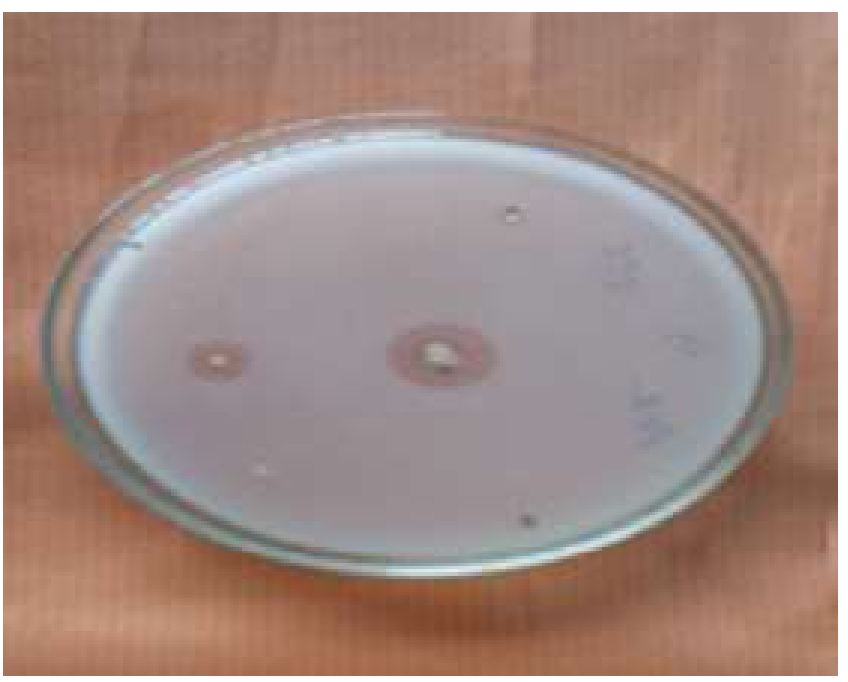

Phostphate solubilzing Bacteria

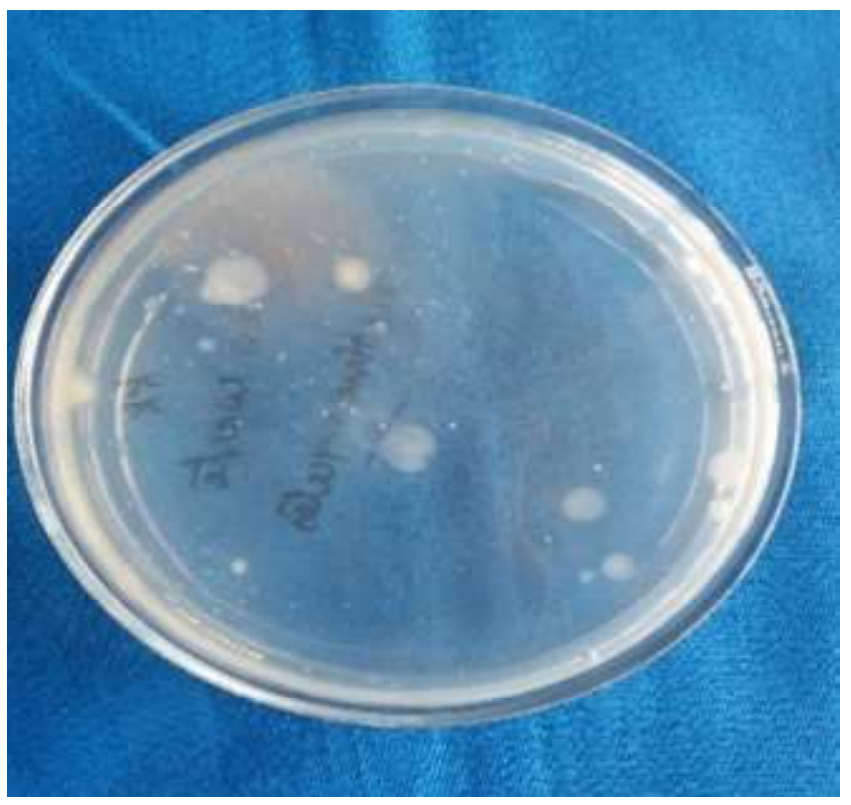

Azospirillum Bacteria

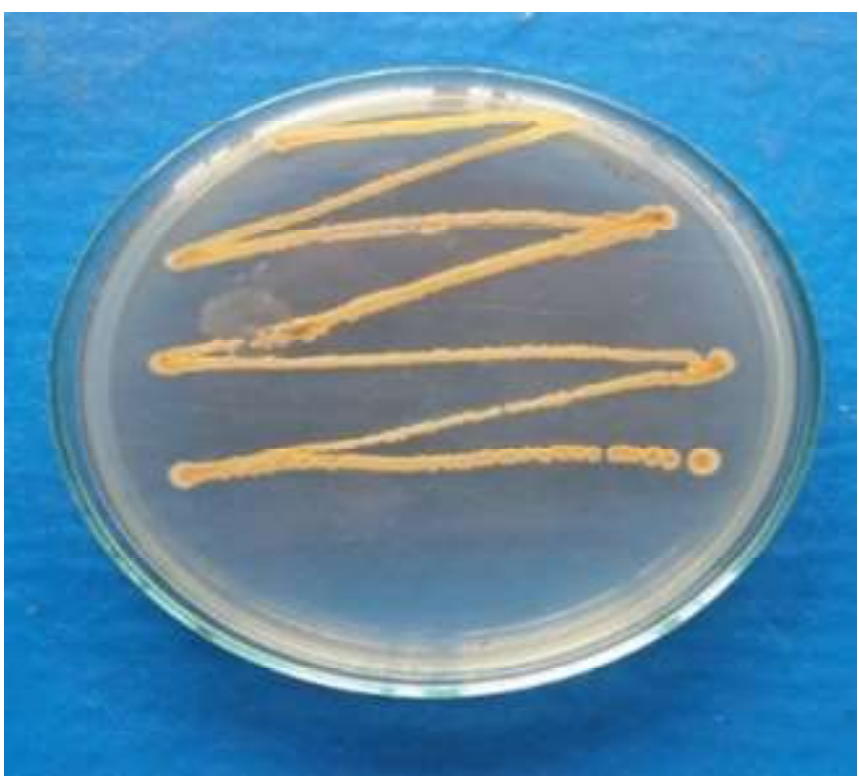

Growth of Azotobacter in Pure Culture

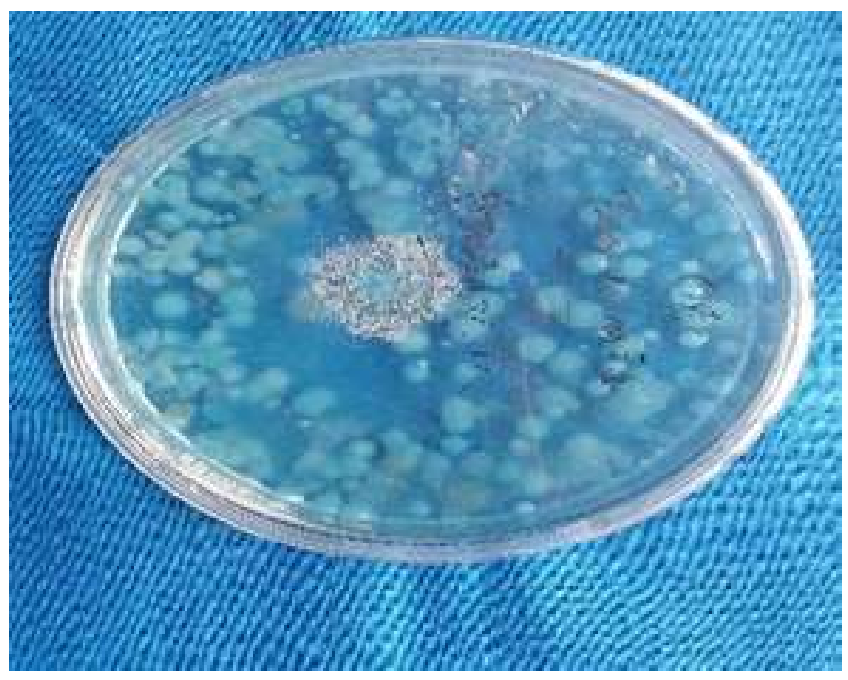

Actinomycetes Bacteria

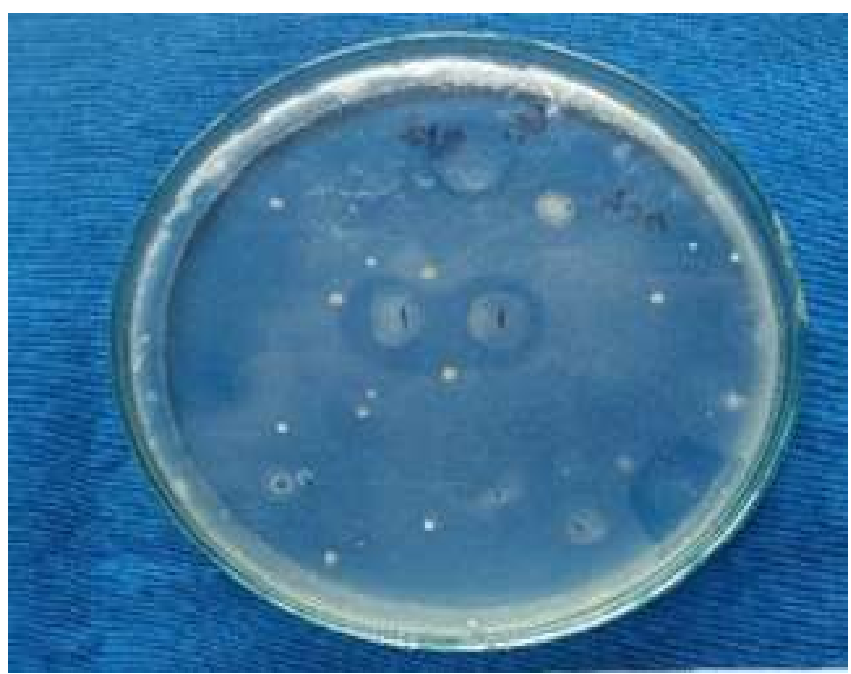

Azotobacter Bacteria

Fig. 1 : Some beneficial microbial population of TFW and PL of Golaghat District of Assam 
which restrain the microbial activity ${ }^{10}$.

\section{Material and Methods \\ Description of the study site:}

Golaghat district of Assam is situated $93^{0} 16^{/}$to $94^{0} 10^{\prime} \mathrm{E}$ and $25^{0} 50^{\prime}$ to $26^{0} 47^{\prime} \mathrm{N}$, total area is $3502 \mathrm{~km}^{2}$.

\section{Sample collection:}

Tea pruning litter samples were collected from study area during 2018-2019. All waste material was collected from 9 tea gardens of Golaghat district of Assam such as Athabari, Behora, Borjan, Doria, Halmora, Hautoli, Hatikhuli, Negheriting and Pavojan tea estate respectively. After collection the waste material was hand shorted according to their size and cut into small pieces and dried in sunlight for 2days to minimize the moisture content. Simultaneously tea waste material were collected from the said factory and carried out to laboratory to determine the physico-Chemical property.

\section{Physico-Chemical properties:}

The Available nitrogen content in TFW sample was analysed $^{11}$ and available phosphate content was determined ${ }^{1}$ and the available potash was estimated ${ }^{3}$ in the department of Soil Tocklai Tea Research Institute, Jorhat, Assam.

\section{Microbial population study method:}

For microbial population study serial dilution techniques $^{13}$. $10.0 \mathrm{~g}$ of tea factory waste (TFW) and pruning litter $(\mathrm{PL})$ were taken in $250 \mathrm{ml}$ conical flask containing $100 \mathrm{ml}$ sterile distilled water and frantic for 10 to 15 minutes. 20 folds series dilution was prepared of both the samples and the dilution was made upto $10^{4}$ dilution of tea waste and $10^{7}$ dilution of pruning litter. 1.0 $\mathrm{ml}$ of the suspension was plated in petriplates with specific media for isolation of microbes like actinomycetes, azotobacter, azospirillum and phosphate solubilizing bacteria. Four different media such as Kenknight (KK), Ashby,s mannitol agar (Asb), Okon,s Media (Oko) and Pikovskaya,s Agar (PKV) medium were used to isolate the four major functional groups of microorganisms. Bacterial plates were incubated at $28^{\circ} \mathrm{C}$ for 2 days while the cultures of actinomycestes were observed at $25^{\circ} \mathrm{C}$ after 5 days of incubation period. The plates were measured for the viable colonies and estimated. Pure colonies were transferred to PDA slants and stored at $4^{0}$ $\mathrm{C}$ in the culture collection laboratory for further identification. The bacterial colonies were counted, subcultured and subsequently purified by streak plate methods $^{2}$. Fungal isolates were characterized based on cultural and morphological characteristics of spores and hyphae mounted in lactophenol and identified by consulting standard taxonomic monographs ${ }^{4,5}$.

\section{Result and Discussion}

The physico-chemical properties of TFW were recorded (Table-1). The highest amount of total nitrogen was found in Pavojan (2.60\%) tea estate and lowest in Negheriting $(2.40 \%)$ tea estate. The highest total phosphate was recorded in Pavijan $(0.58 \%)$ and lowest in Halmora $(0.45 \%)$. Total potassium was highest in Hatikhuli $(1.67 \%)$ tea estate and lowest in Halmora $(0.45 \%)$. The maximum TSS was found in Halmora $(31.1 \%)$ and minimum was recorded in Negheriting (27.2\%). In Behora (27.78\%) Caffenine was maximum and in Doria (25.83\%) was minimum. The maximum total ash was recorded in Borjan (6.54\%) and minimum was recorded in Behora (3.15) tea estate. The maximum amount of Theaflavins was found in Halmora (0.76\%) and minimum was recorded in Behora $(0.45 \%)$ and the maximum amount of Thearubigins was found in Halmora (21.32\%) and minimum was recorded in Hatikuli (18.45\%) tea estate.

\section{Conclusion}

In Golaghat district 74 numbers of tea gardens are found. From this tea estate large quantity of TFW and PL are produced. Both are important by - products of different tea factories. These materials are reached in beneficial microbes, NPK as well as in total soluble solids, crude fibre, caffenine, cotal ash, theaflavins and thearubigins. These sources have immense potential in producing value added organic substance which will nutritionally improve the tea soil. This will also be a good practice of fruitful management of tea waste.

\section{References}

1. Bray H, Kurtz LT. "Determination of total organic and available forms of phosphorus in soil", Soil Science. 1945; 59( 1 ) : 39issue 1, pp -46.

2. Cappucino JG, Sherman N. Microbiology - a laboratory manual. 7th edn. Pearson Education, Dorling Kindersley (India) Pvt. Ltd. 20004.

3. Chapman HD, Pratt PF. "Methods of analysis for soils, plants and waters", University of California, Los Angeles, 1961; pp 60-61: 150-179.

4. Domesch KH, Gams W, Anderson TH. Compendium of soil fungi. Academic Press, London. 1980. 
5. $\quad$ Gilman JC . A manual of soil fungi. 2nd edn. Ames, U.S.A.: lowa State College Press. 1957.

6. Gourav G, Sinalkar J. Essential nutrients for plant growth: Nutrient function and deficiency symptoms, IJRRS. 2013; 2(3) : pp 301-322.

7. Maudu M, Mudau FN, Mariga IK. The effect of pruning on growth and chemical composition of cultivated bush tea (Athrixia phylicoides D.C). J. Med. Plants Res. 2010; 4 : 2353-2358.

8. Ravichandran $R$. The impact of pruning and time from pruning on quality and aroma constituents of black tea. Food Chem. 2003; 84: 7- 11.

9. Satyanarayana N, Sreedhar CH, Cox S, Sharma VS. Response of tea to pruning height. J. Plant. Crops. 1994; 22: 81-86.

10. Souto XC, Chiapusio G, Pellissier F. Relationships between phenolics and soil microorganisms in spruce forests: significance for natural regeneration 2000: relationships between phenolics and soil microorganisms in spruce forests: significance for natural regeneration. J. Chem. Ecol. 2000; 26 : 2025-2034.

11. Subbiah, B.V and Asija, G.L "A rapid procedure for the determination of available nitrogen in soil", Current Science. 1956; 25: 259-260.

12. Tocklai tea research association. Pruning and skiffing of mature tea. 2008.

13. Travors JT, Cook S. A comparision of plating media and dilution for enumeration of aerobic bacteria in a loam soil, Journal of Microbial methods. 1992; 14: 271-5.

14. Wasewar J. Absorption of metals into tea factory waste: A review, IJRRS. 2010; 3(3) : pp 302-322.

15. Wasewar J. Earthworms use odur cues to locate and feed on Micro-organisms in soil. IJRRS. $2011 ; 4$ (3) : pp 315-330.

16. Weeraratna $C$, Watson $M$, Wettasingha $D$. Effect of mineralization of tea prunings on some soil characteristics. Plant Soil. 1977; 46 : 93-99. doi:10.1007/BF00693116.

17. Yilmaz G, Kandemir N, Kinalioglu K. Effects of different pruning intervals on fresh shoot yield and some quality properties of Tea (Camellia sinensis L. O. Kuntze) in Turkey. Pakistan J. Biol. Sci. 2004; 7: 1208-1212. 